\title{
Therapeutics in Renal Disease: The Road Ahead for Antiproliferative Targets
}

\author{
Peter J. Nelson ${ }^{a}$ Stuart J. Shankland ${ }^{b}$ \\ ${ }^{a}$ Division of Nephrology, New York University School of Medicine, New York, N.Y., and \\ ${ }^{b}$ Division of Nephrology, University of Washington Medical Center, Seattle, Wash., USA
}

\section{Key Words}

New treatments, redundant $\cdot$ Renal function

preservation - Proliferative renal disease .

Small-molecule drugs

\begin{abstract}
Discovery into the molecular basis of renal disease is occurring at an unprecedented rate. With the advent of the NIH Roadmap, there is a greater expectation of translating this knowledge into new treatments. Here, we review the therapeutic strategy to preserve renal function in proliferative renal diseases by directly inhibiting the mitogenic pathways within renal parenchymal cells that promote $G_{0}$ to $G_{1} / S$ cell-cycle phase progression. Reductionist methodologies have identified several antiproliferative molecular targets, and promising preclinical testing of leading small-molecule drugs to modulate these targets has now led to landmark clinical trials. Yet, this advancement into targeted therapy highlights important differences between the therapeutic goals of molecular nephrology versus molecular oncology and, by extension, the poorly understood role of alternative target activity in drug efficacy. Systems research to clarify these issues should accelerate the development of this promising therapeutic strategy.
\end{abstract}

Copyright (C) 2006 S. Karger AG, Basel

\section{Introduction}

Starting from the earliest clinicopathologic correlates and on into the current genomic era of experimental molecular nephrology, the fundamental causal relationship between abnormally increased proliferation of renal parenchyma (i.e., renal glomerular and tubular cells) and loss of nephron function has been validated [1]. Over the last decade, the therapeutic implications of directly targeting this pathogenic phenotype have been increasingly explored, culminating recently in clinical trials for mesangial proliferative glomerulonephritis ${ }^{1,2}$. This progress into targeted therapy for proliferative renal diseases overlaps the commencement of the United States National Institutes of Health (NIH) Roadmap [2]. This significant, ongoing initiative by the NIH is designed to encourage investigators engaged in biomedical research within the public sector to create the research reagents, informatics

1 Seliciclib in IgA Nephropathy Trial by Cyclacel, Limited (www.cyclacel. com). This was a multi-institutional phase II clinical trial to test a small-molecule cyclin-dependent kinase inhibitor in patients with IgA nephropathy. The trial was halted due to the development of adverse events related to drug administration in some patients.

2 Gleevac in IgA Nephropathy Trial by Novartis (www.novartis.com). This was designed as a multi-institutional phase II clinical trial to test a small-molecule platelet-derived growth factor receptor tyrosine kinase inhibitor in patients with IgA nephropathy. The trial was halted due to concerns raised by long-term preclinical toxicity studies in animals.

\section{KARGER}

(C) 2006 S. Karger AG, Basel

Fax +41613061234 E-Mail karger@karger.ch www.karger.com www.karger.com/nee
Peter J. Nelson, MD

Division of Nephrology, OBV-CD696, NYU School of Medicine

550 First Avenue

New York, NY 10016 (USA)

Tel. +1 212263 7681, Fax +1 212263 7683, E-Mail nelsop02@popmail.med.nyu.edu 
platforms and consortiums to facilitate therapeutic translational research (www.nihroadmap.nih.gov). In the light of these advances, we review here the therapeutic strategy to preserve renal function in proliferative renal diseases by directly inhibiting the mitogenic pathways within renal parenchymal cells that promote $G_{0}$ to $G_{1} / S$ cellcycle phase progression. For examples of additional therapeutic strategies for some proliferative renal diseases, the reader is referred to recent reviews on the treatment of glomerulonephritis by Coppo and Amore [3] and Javaid and Quigg [4].

\section{Target Identification}

The identification of therapeutic molecular targets for renal diseases has derived largely from studies to determine either the etiologic or the phenotypic basis for the loss of nephron function. Each of these two categories of targets carries inherent therapeutic risks that are unrelated to any potential toxicity of drug treatment. Molecular targets against specific etiologies (e.g., metabolic in diabetic nephropathy, infectious in collapsing glomerulopathy, immune in membranous nephropathy, genetic in polycystic kidney disease, etc.) risk the presence of 'downstream' pathogenic mechanisms within the diseased renal parenchyma that have become independent of the etiology and, therefore, are not readily halted or reversed if the etiology is eliminated. Examples of this include the activation of signaling cascades and the increased production of cytokines and growth factors at sites of parenchymal injury that persist despite withdrawal or treatment of the inciting etiology. On the other hand, molecular targets against specific pathogenic phenotypes (e.g., apoptotic, fibrotic, etc.) risk reinjury by the etiology and a lack of specificity and efficacy due to a minor contribution of the targeted phenotype to the loss of nephron function.

With these potential therapeutic constraints in mind, it is important to appreciate that the therapeutic strategy to preserve renal function by directly inhibiting mitogenic signaling within glomerular and tubulointerstitial cell types derives from the phenotypic category of targets. This therapeutic strategy is based on the knowledge that physiologic structure-function relationships along the mature nephron require the presence of cell-cycle quiescent, functionally and morphologically differentiated renal parenchyma [1]. Unlike the high physiologic rate of proliferation due to normal cell losses in some organ systems, such as in the gastrointestinal, hematopoietic, or skin, there is very little cell proliferation in normal adult glomeruli and a very low rate of proliferation in tubular cells in a healthy kidney $[5,6]$. Proliferation of renal glomerular and tubular cells is, therefore, considered to be an abnormal phenotype. Thus, following injury, the ability to halt abnormal proliferation of specific renal cell types with antiproliferative therapies should be possible without theoretically harming bystander disease-free nephrons or nephron segments, as these typically have little or no proliferation if nondiseased.

In developing this therapeutic strategy over the last decade (fig. 1), the identification of nearly all 'druggable' antiproliferative molecular targets within the renal parenchyma, ranging from cell surface receptors to nuclear cellcycle regulatory proteins (table 1), has resulted from applying research methodologies designed to detect critical molecules controlling proliferation. These 'reductionist methodologies' were largely developed and refined in molecular oncology, where one central theory for the cause of proliferative disease is its reducibility to the pathogenic loss- or gain-of-function of specific molecules within the neoplastic cell [7]. The wide success of these reductionist methodologies in molecular nephrology is evidenced by the fact that several target/drug pairs currently under investigation (table 1) were first characterized through studies in molecular oncology.

Caveats clearly exist, however, in stating a general applicability of molecular oncology targets or target/drug pairs to proliferative renal diseases, as follows. First, the ultimate desired therapeutic goal of targeted therapy in molecular oncology is to eliminate neoplastic, malignant growth (cytotoxic growth arrest irrespective of cell cycle phase) within otherwise normal tissue domains [8]. In contrast, the desired therapeutic goal in molecular nephrology is to promote cell-cycle quiescence, cell differentiation, and tissue remodeling at sites of proliferative injury within the kidney. These therapeutic responses are most likely to occur during cytostatic growth arrest in the $\mathrm{G}_{0} / \mathrm{G}_{1}$ phase of the renal cell-cycle, the physiologic state of normal glomerular and tubular renal cells. If this is indeed correct, it may render targets that induce nonphysiologic growth arrest beyond the $\mathrm{G}_{1} / \mathrm{S}$ boundary, such as mitotic spindle disruption, problematic in the kidney (fig. 2). Second, targets or target/drug pairs in the mitogenic signaling cascade from $G_{0}$ to the $G_{1} / S$ boundary may be characterized for their ability to induce cytotoxicity over other phenotypic responses, thereby minimizing important knowledge of additional target activities of therapeutic relevance [8]. Lastly, the prolonged and continuous courses of therapy (and the potential related toxicities) that may be required to treat some indolent pro- 
Fig. 1. Flow chart in the development of a therapeutic strategy. The first step is to identify a potential drug target that is predicted to disrupt a critical step in the pathogenesis of disease. The chosen target may harbor alternative target activity that together increases overall efficacy. This alternative target activity may be due to the ability of a chosen target to control multiple cellular processes involved in the pathogenesis of the disease, a therapeutic activity termed 'target pleiotropy', and/or to the existence of unintended or unknown off-targets to the chosen target that are also involved in the pathogenesis of the disease, a therapeutic activity termed 'target paralogy'. However, target pleiotropy and target paralogy can confuse the therapeutic role of the chosen target if the contribution of the former to efficacy is poorly understood. Drug entities are typically screened and selected for their ability to modulate the chosen target in vitro; it may be discovered after a drug is developed that the drug itself harbors therapeutically relevant alternative target activity, raising questions about the specificityof-action of the drug. Once a drug entity is identified, it must exhibit favorable absorption, distribution, metabolism, excretion, and toxicity (ADMET) in order to at least undertake proof-of-concept studies of the therapeutic strategy in vivo to proceed to clinical trials. At this stage, the best measurements of efficacy include biomarkers (see table 2) that either directly detect or accurately predict the specificity of drug action in preclinical models and in humans.

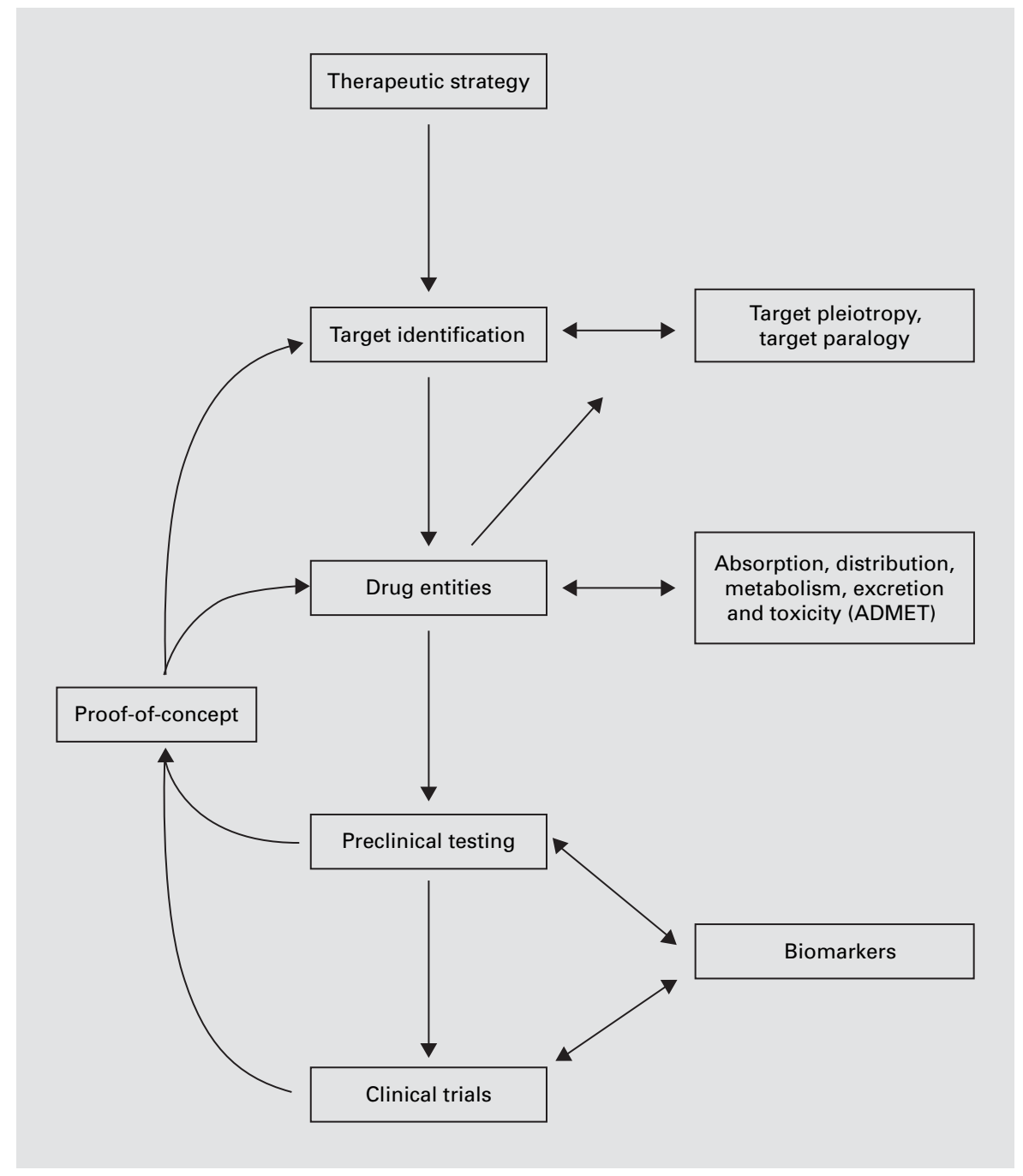

Fig. 2. Depiction of the cell-cycle domain of antiproliferative targets in proliferative renal diseases. Molecular oncology targets favor cytotoxic growth arrest of malignant cells and, therefore, have been identified in all phases of the cell-cycle, i.e., $\mathrm{G}_{1}, \mathrm{~S}, \mathrm{G}_{2}$, and $\mathrm{M}$ (box A). In contrast, ideal targets in molecular nephrology largely fall within the cell-cycle phase from $\mathrm{G}_{0}$ to the $\mathrm{G}_{1} / \mathrm{S}$ cell cycle checkpoint (box B), the phase where physiologic growth arrest can be achieved. Targets beyond the $G_{1} / S$ cell-cycle checkpoint induce an undesirable, nonphysiologic state of growth arrest and are often cytotoxic to cells.

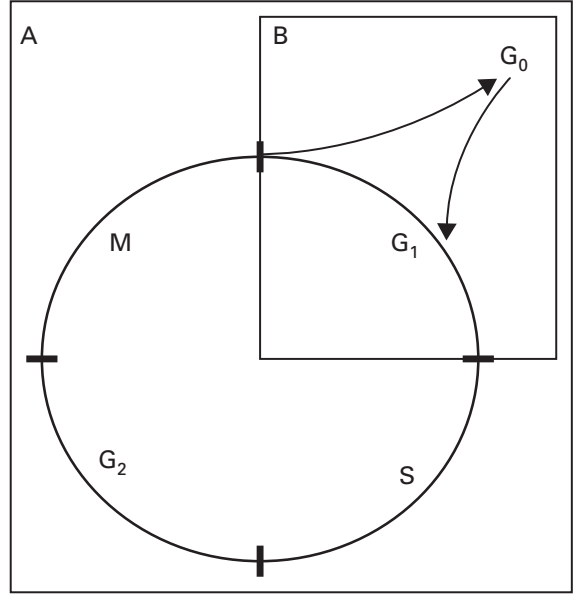

Nelson/Shankland 
Table 1. Antiproliferative molecular targets studied in models of proliferative renal disease

\begin{tabular}{|c|c|c|c|c|c|}
\hline Molecular target & Drug entity ${ }^{\mathrm{a}}$ & Renal cell model & Animal model (human disease) & Proposed mechanism $^{\mathrm{c}}$ & $\begin{array}{l}\text { Ref- } \\
\text { erences }\end{array}$ \\
\hline $\begin{array}{l}\text { Cyclin-dependent kinases } \\
\text { (CDK) }\end{array}$ & $\begin{array}{l}\text { flavopiridol, } \\
\text { roscovitine, } \\
\text { TNP-470 }\end{array}$ & $\begin{array}{l}\text { mouse podocyte, } \\
\text { rat mesangial }\end{array}$ & $\begin{array}{l}\text { mouse Tg26 (collapsing } \\
\text { glomerulopathy), rat anti-Thy } 1.1 \\
\text { (mesangial proliferative } \\
\text { glomerulonephritis), mouse anti- } \\
\text { glomerular protein (collapsing } \\
\text { glomerulopathy) }\end{array}$ & $\begin{array}{l}\text { inhibit } \mathrm{G}_{1} / \mathrm{S} \text { cell-cycle } \\
\text { phase progression by } \\
\text { preventing } C D K \text { activity }\end{array}$ & $27-32$ \\
\hline $\begin{array}{l}\text { Epidermal growth factor } \\
\text { receptor tyrosine kinase } \\
\text { (EGFRTK) }\end{array}$ & $\begin{array}{l}\text { EKB-569, } \\
\text { EKI-785 }\end{array}$ & $\begin{array}{l}\text { rodent kidney } \\
\text { explants }\end{array}$ & $\begin{array}{l}\text { mouse BPK (polycystic kidney } \\
\text { disease), } \\
\text { rat Han:SPRD (polycystic kidney } \\
\text { disease) }\end{array}$ & $\begin{array}{l}\text { inhibits EGFRTK activity } \\
\text { by preventing EGFR auto- } \\
\text { phosphorylation }\end{array}$ & $33-36$ \\
\hline $\begin{array}{l}\text { 3-Hydroxy-3-methyl- } \\
\text { glutaryl-CoA reductase } \\
\text { (HMG-CoA) }\end{array}$ & $\begin{array}{l}\text { lovastatin }^{\mathrm{b}}, \\
\text { pravastatin }^{\mathrm{b}}, \\
\text { simvastatin }^{\mathrm{b}}\end{array}$ & $\begin{array}{l}\text { human mesangial, } \\
\text { rat epithelium, } \\
\text { rat mesangail }\end{array}$ & $\begin{array}{l}\text { rat anti-Thy } 1.1 \text { (mesangial } \\
\text { proliferative glomerulonephritis), rat } \\
\text { Han:SPRD (polycystic kidney disease) }\end{array}$ & $\begin{array}{l}\text { inhibits prenylation of } \\
\text { GTPases by preventing } \\
\text { synthesis of isoprenoid }\end{array}$ & $37-47$ \\
\hline $\begin{array}{l}\text { Mammalian target of } \\
\text { rapamycin (mTOR) }\end{array}$ & rapamycin ${ }^{b}$ & $\begin{array}{l}\text { human epithelium, } \\
\text { mouse epithelium }\end{array}$ & $\begin{array}{l}\text { rat Han:SPRD (polycystic kidney } \\
\text { disease) }\end{array}$ & $\begin{array}{l}\text { inhibits translation of cell- } \\
\text { cycle control genes }\end{array}$ & $48-50$ \\
\hline $\begin{array}{l}\text { Peroxisome-proliferator- } \\
\text { activated receptor gamma } \\
(\operatorname{PPAR} \gamma)\end{array}$ & $\begin{array}{l}\text { ciglitazone }^{\mathrm{b}}, \mathrm{L}-805645, \\
\text { pioglitazone }^{\mathrm{b}} \\
\text { troglitazone }^{\mathrm{b}}, 15 d-\mathrm{PGJ}_{2}\end{array}$ & $\begin{array}{l}\text { human fibroblast, } \\
\text { mouse mesangial, } \\
\text { rat mesangial }\end{array}$ & $\begin{array}{l}\text { rat anti-glomerular basement } \\
\text { membrane (crescentic } \\
\text { glomerulonephritis) }\end{array}$ & $\begin{array}{l}\text { inhibits serum-responsive } \\
\text { genes by activation of } \\
\text { PPAR } \gamma \text {-responsive elements }\end{array}$ & $51-54$ \\
\hline Phosphodiesterases & $\begin{array}{l}\text { cilostamide, } \\
\text { cilostazol }^{\mathrm{b}} \text {, } \\
\text { lixazinone, } \\
\text { pentoxifylline } \\
\text { rolipram }\end{array}$ & $\begin{array}{l}\text { human fibroblast, } \\
\text { rat mesangial }\end{array}$ & $\begin{array}{l}\text { rat folate-induced, rat anti-Thy } 1.1 \\
\text { (mesangial proliferative } \\
\text { glomerulonephritis) }\end{array}$ & $\begin{array}{l}\text { inhibit raf signaling by } \\
\text { activating PKA through } \\
\text { raising cAMP levels }\end{array}$ & $55-59$ \\
\hline $\begin{array}{l}\text { Platelet-derived growth } \\
\text { factor receptor (PDGFR) }\end{array}$ & trapidil $^{b}$ & rat mesangial & $\begin{array}{l}\text { rat anti-Thy } 1.1 \text { (mesangial } \\
\text { proliferative glomerulonephritis) }\end{array}$ & $\begin{array}{l}\text { inhibits PDGFR activation } \\
\text { by preventing PDGF } \\
\text { binding to PDGFR }\end{array}$ & 60,61 \\
\hline $\begin{array}{l}\text { Platelet-derived growth } \\
\text { factor receptor tyrosine } \\
\text { kinase (PDGFRTK) }\end{array}$ & $\begin{array}{l}\text { imatinib mesylate }{ }^{\mathrm{b}} \text {, } \\
\text { Ki6783 }\end{array}$ & rat mesangial & $\begin{array}{l}\text { rat anti-Thy } 1.1 \text { (mesangial } \\
\text { proliferative glomerulonephritis) }\end{array}$ & $\begin{array}{l}\text { inhibits PDGFRTK activity } \\
\text { by preventing PDGFR } \\
\text { autophosphorylation }\end{array}$ & 62,63 \\
\hline Prostacyclin receptor & beraprost sodium & rat mesangial & $\begin{array}{l}\text { mouse MZB/W (lupus } \\
\text { glomerulonephritis), } \\
\text { rat anti-glomerular basement } \\
\text { membrane (crescentic } \\
\text { glomerulonephritis) }\end{array}$ & $\begin{array}{l}\text { inhibits ERK signaling by } \\
\text { inducing MAPK } \\
\text { phosphatase }\end{array}$ & $64-68$ \\
\hline Ras & $\begin{array}{l}\text { S-trans, trans- } \\
\text { farnesylthiosalicylic } \\
\text { acid }\end{array}$ & rat mesangial & $\begin{array}{l}\text { rat anti-Thy } 1.1 \text { (mesangial } \\
\text { proliferative glomerulonephritis) }\end{array}$ & $\begin{array}{l}\text { inhibits ras activity by } \\
\text { preventing ras membrane } \\
\text { localization }\end{array}$ & 69 \\
\hline $\begin{array}{l}\text { Retinoic acid receptor } \\
\text { (RAR/RXR) }\end{array}$ & $\begin{array}{l}\text { AGN 194204, } \\
\text { AGN 195183, } \\
\text { all-trans-retinoate }^{\mathrm{b}}, \\
\text { BMS-453, isotretinoin }^{\mathrm{b}} \text {, } \\
\text { n-(4-hydroxyphenyl) } \\
\text { retinamide, } \\
\text { RO-13740, RO-257386 }\end{array}$ & $\begin{array}{l}\text { human epithelium, } \\
\text { canine epithelium, } \\
\text { rat epithelium, } \\
\text { rat mesangial }\end{array}$ & $\begin{array}{l}\text { rat anti-Thy } 1.1 \text { (mesangial } \\
\text { proliferative glomerulonephritis), } \\
\text { mouse anti-glomerular protein } \\
\text { (collapsing glomerulopathy) }\end{array}$ & $\begin{array}{l}\text { inhibits expression of fos, } \\
\text { jun, and GATA-2 by } \\
\text { activation of RAR/RXR- } \\
\text { responsive elements }\end{array}$ & $70-76$ \\
\hline $\begin{array}{l}\text { Vasopressin } \mathrm{V}_{2} \text { receptor } \\
\text { (VPV2R) }\end{array}$ & $\begin{array}{l}\text { OPC-31260, } \\
\text { OPC-41061 }\end{array}$ & human epithelium & $\begin{array}{l}\text { mouse pcy (nephronophthisis), mouse } \\
\text { Pkd2-/tm1Som (polycystic kidney } \\
\text { disease), rat PCK (polycystic kidney } \\
\text { disease) }\end{array}$ & $\begin{array}{l}\text { inhibits paradoxical, } \mathrm{Ca}^{2+}- \\
\text { dependent raf activation by } \\
\text { PKA through lowering } \\
\text { cAMP levels }\end{array}$ & $77-82$ \\
\hline
\end{tabular}

\footnotetext{
a Small molecules are listed; other types of drugs have been studied for some targets.

${ }^{\mathrm{b}}$ FDA-approved.

${ }^{c}$ Proposed in renal systems; mechanism may differ in other systems.
} 
Table 2. Biomarkers in proliferative renal diseases [adapted from ref. 10]

Type I

- Designed to directly detect modulation of drug target activity

- Can be problematic, if unforeseen drug targets are also captured by the biomarker

- Examples:

Protein substrates of kinase targets

Metabolic products of enzymatic targets

Genes under the control of transcription factor targets

Type II

- Commonly referred to as surrogate markers

- Do not directly capture the specificity of drug action

- Examples:

Quantitative immunohistopathology for PCNA or Ki-67 expression

Urinary or serologic indices of renal function

Whole-kidney size or weight

liferative renal diseases, such as polycystic kidney disease and IgA nephropathy, may halt investigation of some targets or target/drug pairs at proof-of-concept of the therapeutic strategy, necessitating the identification of additional targets or new drug entities (fig. 1). For example, the marked improvement in renal function with little adverse effect from targeting cyclin-dependent kinases in renal parenchyma with the small molecule roscovitine (CYC202, seliciclib) has been validated across a range of preclinical models (table 1 and [ref. 83]). However, the adverse events secondary to continuous drug dosing that occurred in some patients in the Seliciclib in IgA Nephropathy Trial were not anticipated by preclinical studies nor by intermittent dosing schedules defined in antecedent phase I oncology studies.

\section{Alternative Target Activity}

The therapeutic response to a drug in vivo (i.e., efficacy) is ascribed to several factors and is essentially the sum of the specific intended action against known targets and the actions against unintended or unknown targets. The latter is called target paralogy [9]. This complex relationship between a drug's efficacy and its specificity of action is amplified by the potential involvement of any one target in multiple cellular processes. This is known as target pleiotropy [9]. Thus, as a drug's alternative target activity (i.e., target paralogy and target pleiotropy) increases, so too does the probability for ambiguity between perceived efficacy and specificity of drug action captured by surrogate/type II biomarkers and type I biomarkers (table 2), respectively [10]. We will use empiric antiviral therapy for the major proliferative renal disease seen in HIV-infected patients, collapsing glomerulopathy, as an example to illustrate this ambiguity. Some groups are investigating the possibility that highly active antiretroviral therapy (HAART) may inhibit the life cycle of HIV within infected renal epithelium, thereby disrupting what is hypothesized as a central pathogenic step in HIV-induced collapsing glomerulopathy. If this is true, the plasma HIV-1 RNA levels may serve as a good correlate for the specificity of HAART activity on HIV-encoded drug targets within renal parenchymal cells - i.e., plasma HIV-1 RNA levels are a true-positive surrogate marker of the antiviral activity of HAART within the renal epithelium [11]. Alternatively, inhibition of the life cycle of HIV by HAART in cell types outside of the renal epithelium (e.g., in infected CD4+ lymphocytes, macrophages, or dendritic cells) or direct modulation by HAART of targets derived from the host, not of targets encoded by HIV, might confer efficacy. If these latter possibilities are true, plasma HIV-1 RNA levels would be a false-positive and falsenegative surrogate marker, respectively, for any antiviral activity of HAART within the renal epithelium [10]. Indeed, these latter therapeutic mechanisms of HAART have already been shown to be important in other nonrenal HIV-associated proliferative diseases [12].

Taken together, we suggest that because there is likely a multifactorial basis for most proliferative renal diseases, all current targets or target/drug pairs under investigation (table 1) are similarly challenged to define specificity of action. In contrast to the desire to eliminate malignant cell growth in the oncology field, where modulation of drug targets in nonmalignant tissue is often trivialized (unless toxic) [8], alternative target activity may contribute significantly to drug efficacy in proliferative renal diseases. One known pleiotropic effect from modulating antiproliferative targets is the concomitant effect on other undesirable pathways, such as inflammatory, fibrogenic, and secretory pathways $[13,14]$, that have harnessed the same target for activity. These additional pathways are referred to as 'target-sharing' pathways which have been aberrantly coactivated and likely also contribute to tissue injury and loss of nephron function. However, the primary intent of promoting cell-cycle quiescence in the renal parenchyma by inhibiting proliferation and any secondary pleiotropic benefit quickly lose definition, if alternative and therapeutically relevant targets exist either within or outside the kidney. 
The recent renal clinical trial target/drug entrant, platelet-derived growth factor receptor/imitanib mesylate (Gleevec/Glivec), illustrates this fact. Imitanib mesylate, an FDA-approved small-molecule drug of the family of the pyrido[2,3- $d$ ] pyrimidines [15], was considered for clinical trials on patients with IgA nephropathy to inhibit platelet-derived growth factor receptor tyrosine kinase activity within the renal parenchyma. Imatinib mesylate and its derivatives also inhibit tyrosine kinases that are highly similar to the platelet-derived growth factor receptor such as fibroblast growth factor receptor, c-kit, and Bcr-Abl [16]. By baiting with immobilized drug, Wissing et al. [16] recently discovered that this drug class binds and more potently inhibits the serine/threonine kinases RICK and p38 $\alpha$ based on a shared specificity determining threonine residue across seemingly disparate kinase domains. This activity conferred previously unknown potent anti-inflammatory properties to this drug class that is independent of its antiproliferative activity [16]. Moreover, imatinib mesylate was also recently discovered to modulate adaptive immune responses by inhibiting $\mathrm{T}$ lymphocyte proliferation and dendritic cell differentiation, reportedly through its known tyrosine kinase targets [17-19]. Since targeting the inflammatory, immunologic component of IgA nephropathy may be efficacious [20], these new therapeutic mechanisms for imatinib mesylate may have misdirected subsequent steps, such as the selection of newer drug entities and appropriate biomarkers, in the development of this particular therapy. While any decision to investigate a potential target or target/drug pair is made with incomplete knowledge, this example highlights the growing need for systems research to delineate the contribution of alternative target activity to drug efficacy in proliferative renal diseases.

\section{Systems Biology}

In part due to the rapidly expanding repertoire of potential targets in proliferative renal diseases, there is a growing appreciation for identifying targets that may carry therapeutic activity in addition to inhibiting proliferation of the renal parenchyma. In practice, this requires an integrative approach to proliferative renal disease biology - often called a 'systems biology' approach - to identify these exceptional targets. For example, unlike reductionist methodologies applied to one disease phenotype, systems biology approaches to target identification are currently being designed to select molecular targets that emerge from integrating a broad range of disease biology, with the goal that these targets may impart the greatest therapeutic impact [21]. These systems-biology-derived targets have been coined 'nodes', because they are predicted to function simultaneously in several pathogenic pathways that together contribute to the development of disease [21]. Thus, modulation of these 'nodes' with drugs may be very effective at reconfiguring the entire disease state back towards normal [21].

However, theoretical, this analytic approach provides a useful framework to investigate the therapeutic role of target pleiotropy and target paralogy that results from applying reductionist methodologies to proliferative renal diseases. By assuming post hoc that a target (intended or unintended) may affect any aspect of proliferative renal disease biology, one can ask whether modulation of that target in renal parenchymal cell types or in other cell types contributes to (and may be paramount in) or is nonparticipatory to perceived efficacy [21]. It may be discovered, for example, that the target directly impacts mitogenic pathways within the renal parenchyma, other renal parenchymal phenotypes that contribute to the loss of nephron function, extrarenal disease phenotypes (an important consideration in multisystem diseases), or the proposed etiology, if known (fig. 3).

Alternative target activity that increases the overall efficacy-to-toxicity ratio (i.e., increases the therapeutic index) would be clearly desirable, whereas exacerbation of disease phenotypes or other adverse outcomes may eliminate or limit the applicability of specific targets or target/ drug pairs. For example, modulation of the mammalian target of rapamycin (mTOR) within the renal epithelium may be efficacious for polycystic kidney disease (table 1), but will require a better understanding of how prolonged CD4+ T lymphocyte anergy (with its potential pitfalls) may contribute, if at all, to perceived efficacy. In contrast, modulation of this same target within mesangial cells in mesangial proliferative glomerulonephritis appears to significantly worsen mesangial remodeling, reportedly due to suppression of mesangial cell migration, but may also involve a paradoxical proinflammatory lymphoid response $[22,23]$. Yet, to date, the quest to answer these types of systems-based questions on intended and untended target activity across a range of cell types in vivo has been hampered by the lack of type I biomarkers [10]. Indeed, the failure of surrogate/type II biomarkers to predict the specificity of drug action is addressed by NIH Roadmap initiatives to develop molecular probes of small-molecule activity [2], a needed step towards systems research in proliferative renal diseases. 
Fig. 3. Interrogation of targets through systems research in proliferative renal diseases. a The systems biology approach to target identification integrates the interaction of elements of disease biology (depicted by the interaction of circles ' $\mathrm{A}$ ' through 'D') to identify emergent, high-impact targets, coined 'nodes', that are predicted to function simultaneously in several pathogenic pathways that together contribute to the development of disease. When modulated with drugs, these nodes will theoretically reconfigure the entire disease state back towards normal. b By assuming that any one target (intended or unintended) identified through reductionist methodologies may affect any aspect of proliferative renal disease biology, one can ask if modulation of that one target impacts important parameters of disease, such as parenchymal hyperplasia, other secondary parenchymal disease phenotypes, extrarenal disease phenotypes, or the etiology.

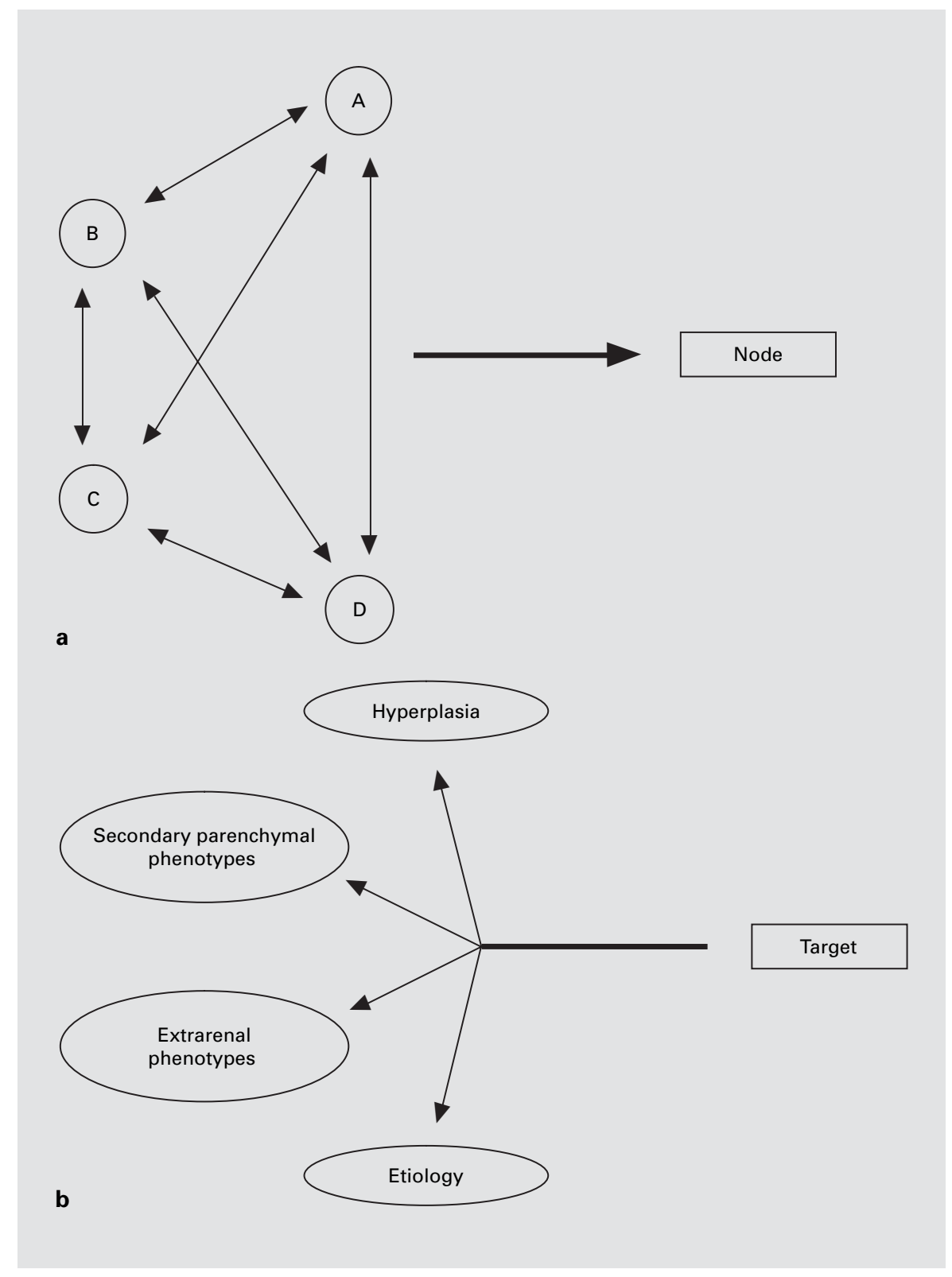

\section{Drug Entities}

The current drive to explore FDA-approved or other well-developed drug entities that modulate antiproliferative targets in renal cells affected by specific disease processes is predicated not only on the hope for favorable pharmacology in their off-label application to renal disease [24], but also on the calculation that these drug entities will provide a greater therapeutic index over existing therapies. This is no trivial motivation, as the vast majority of promising new drug entities detected through in vitro screens subsequently fail in preclinical and clinical development due to problems with absorption, distribution, metabolism, excretion, or toxicity (ADMET) [25]. However, since no drug entities investigated to date for use in proliferative renal diseases were specifically developed for this disease indication (table 1), it must be remembered that important factors, such as renal insufficiency and adjuvant therapy, can profoundly influence drug pharmacokinetics and dynamics (e.g., as was shown for mycophenolic acid, a nontargeted therapy in clinical trials for a number of renal diseases) [26]. In any respect, 
NIH Roadmap initiatives to provide interrogational small-molecule libraries and predictive ADMET technology to the public sector are poised to change this trend in the future [2].

\section{Conclusions}

The development of a therapeutic strategy from target identification to clinical trials is one of the most challenging and complex research endeavors in both industry and academia. Notwithstanding, research to explore the therapeutic strategy that renal function may be preserved in proliferative renal diseases by directly inhibiting $G_{0}$ to $\mathrm{G}_{1} / \mathrm{S}$ cell-cycle phase progression in the renal parenchyma has made significant progress over the last decade. The application of reductionist methodologies has created a rapidly expanding repertoire of potential targets, and pre- clinical testing of well-developed drug entities that modulate many of these targets has validated this therapeutic strategy across a range of models. Yet, because many pathogenic factors cooperate to induce most proliferative renal diseases, the ability to clearly link drug efficacy to modulation of intended targets is often elusive, a challenge that may best be addressed by rigorous systemsbased research.

\section{Acknowledgements}

We thank Sharon Adler and Anna Barnett for helpful discussions on clinical trials in IgA nephropathy. P.J.N. is supported by NIH grant DK065498. S.J.S. is supported by NIH grants(DK60525, DK56799, and DK51096) and the American Diabetes Association and is an Established Investigator of the American Heart Association.

\section{References}

1 Shankland SJ: Cell-cycle control and renal disease. Kidney Int 1997;52:294-308.

2 Zerhouni E: Medicine. The NIH Roadmap. Science 2003;302:63-72.

3 Coppo R, Amore A: New perspectives in treatment of glomerulonephritis. Pediatr Nephrol 2004;19:256-265.

-4 Javaid B, Quigg R: Treatment of glomerulonephritis: will we ever have options other than steroids and cytotoxics? Kidney Int 2005;67: 1692-1703.

-5 Pabst R, Sterzel RB: Cell renewal of glomerular cell types in normal rats. an autoradiographic analysis. Kidney Int 1983;24:626-631.

6 Nadasdy T, Laszik Z, Blick KE, et al: Proliferative activity of intrinsic cell populations in the normal human kidney. J Am Soc Nephrol 1994;4:2032-2039.

7 Soto AM, Sonnenschein C: The somatic mutation theory of cancer: growing problems with the paradigm? Bioessays 2004;26:1097-1107.

-8 Stadler WM, Ratain MJ: Development of target-based antineoplastic agents. Invest New Drugs 2000;18:7-16.

-9 Searls DB: Pharmacophylogenomics: genes, evolution and drug targets. Nat Rev Drug Discov 2003;2:613-623.

10 Frank R, Hargreaves R: Clinical biomarkers in drug discovery and development. Nat Rev Drug Discov 2003;2:566-580.

11 Szczech LA, Gupta SK, Habash R, et al: The clinical epidemiology and course of the spectrum of renal diseases associated with HIV infection. Kidney Int 2004;66:1145-1152.

12 Monini P, Sgadari C, Toschi E, et al: Antitumour effects of antiretroviral therapy. Nat Rev Cancer 2004;4:861-875.
13 Alton G, Schwamborn K, Satoh Y, et al: Therapeutic modulation of inflammatory gene transcription by kinase inhibitors. Expert Opin Biol Ther 2002;2:621-632.

14 Torres VE: Cyclic AMP, at the hub of the cystic cycle. Kidney Int 2004;66:1283-1285.

$\checkmark 15$ Capdeville R, Buchdunger E, Zimmermann J, et al: Glivec (STI571, imatinib), a rationally developed, targeted anticancer drug. Nat Rev Drug Discov 2002;1:493-502.

16 Wissing J, Godl K, Brehmer D, et al: Chemical proteomic analysis reveals alternative modes of action for pyrido[2,3- $d$ ]pyrimidine kinase inhibitors. Mol Cell Proteomics 2004;3:11811193.

17 Cwynarski K, Laylor R, Macchiarulo E, et al: Imatinib inhibits the activation and proliferation of normal $\mathrm{T}$ lymphocytes in vitro. Leukemia 2004; 18:1332-1339.

18 Dietz AB, Souan L, Knutson GJ, et al: Imatinib mesylate inhibits T-cell proliferation in vitro and delayed-type hypersensitivity in vivo. Blood 2004; 104:1094-1099.

19 Appel S, Boehmler AM, Grunebach F, et al: Imatinib mesylate affects the development and function of dendritic cells generated from CD34+ peripheral blood progenitor cells. Blood 2004; 103:538-544.

20 Julian BA, Novak J: IgA nephropathy: an update. Curr Opin Nephrol Hypertens 2004; 13 : 171-179.

21 Butcher EC, Berg EL, Kunkel EJ: Systems biology in drug discovery. Nat Biotechnol 2004;22: 1253-1259.
22 Daniel C, Ziswiler R, Frey B, et al: Proinflammatory effects in experimental mesangial proliferative glomerulonephritis of the immunosuppressive agent SDZ RAD, a rapamycin derivative. Exp Nephrol 2000;8:52-62.

$>23$ Daniel C, Pippin J, Shankland SJ, et al: The rapamycin derivative RAD inhibits mesangial cell migration through the CDK-inhibitor p27KIP1. Lab Invest 2004;84:588-596.

$>24$ Bennett WM: Off-label use of approved drugs: therapeutic opportunity and challenges. J Am Soc Nephrol 2004; 15:830-831.

25 Lin JH, Lu AY: Role of pharmacokinetics and metabolism in drug discovery and development. Pharmacol Rev 1997;49:403-449.

26 Meier-Kriesche HU, Shaw LM, Korecka M, et al: Pharmacokinetics of mycophenolic acid in renal insufficiency. Ther Drug Monit 2000;22: 27-30.

27 Pippin J, Qu Q, Meijer L, et al: Direct in vivo inhibition of the nuclear cell cycle cascade in experimental mesangial proliferative glomerulonephritis with roscovitine, a novel cyclin-dependent kinase antagonist. J Clin Invest 1997; 100:2512-2520.

28 Nelson PJ, Gelman IH, Klotman PE: Suppression of HIV-1 expression by inhibitors of cyclin-dependent kinases promotes differentiation of infected podocytes. J Am Soc Nephrol 2001;12:2827-2831.

29 Nelson PJ, D’Agati VD, Gries JM, et al: Amelioration of nephropathy in mice expressing HIV-1 genes by the cyclin-dependent kinase inhibitor flavopiridol. J Antimicrob Chemother 2003;51:921-929. 
-30 Gherardi D, D'Agati V, Chu TH, et al: Reversal of collapsing glomerulopathy in mice with the cyclin-dependent kinase inhibitor CYC202. J Am Soc Nephrol 2004;15:1212-1222.

- 31 Haraguchi M, Okamura M, Konishi M, et al: Anti-angiogenic compound (TNP-470) inhibits mesangial cell proliferation in vitro and in vivo. Kidney Int 1997;51:1838-1846.

- 32 Griffin SV, Krofft R, Pippin JW, et al: Limitation of podocyte proliferation improves renal function in experimental crescentic glomerulonephritis. Kidney Int 2005;67:977-986.

- 33 Sweeney WE, Futey L, Frost P, et al: In vitro modulation of cyst formation by a novel tyrosine kinase inhibitor. Kidney Int 1999;56:406413.

-34 Sweeney WE, Chen Y, Nakanishi K, et al: Treatment of polycystic kidney disease with a novel tyrosine kinase inhibitor. Kidney Int 2000;57:33-40.

- 35 Sweeney WE Jr, Hamahira K, Sweeney J, et al: Combination treatment of PKD utilizing dual inhibition of EGF-receptor activity and ligand bioavailability. Kidney Int 2003;64:13101319.

- 36 Torres VE, Sweeney WE Jr, Wang X, et al: EGF receptor tyrosine kinase inhibition attenuates the development of PKD in Han:SPRD rats. Kidney Int 2003;64:1573-1579.

- 37 Nishimura M, Tanaka T, Yasuda T, et al: Effect of pravastatin on type IV collagen secretion and mesangial cell proliferation. Kidney Int Suppl 1999;71:S97-S100.

- 38 Nishimura M, Tanaka T, Yasuda T, et al: Collagen secretion and growth of mesangial cells require geranylgeranylpyrophosphate. Kidney Int 1999;55:520-528.

- 39 O'Donnell MP, Kasiske BL, Kim Y, et al: Lovastatin inhibits proliferation of rat mesangial cells. J Clin Invest 1993;91:83-87.

-40 Guijarro C, Kim Y, Schoonover CM, et al: Lovastatin inhibits lipopolysaccharide-induced NF-kappaB activation in human mesangial cells. Nephrol Dial Transplant 1996;11:990996.

-41 Gile RD, Cowley BD Jr, Gattone VH 2nd, et al: Effect of lovastatin on the development of polycystic kidney disease in the Han:SPRD rat. Am J Kidney Dis 1995;26:501-507.

-42 Massy ZA, Guijarro C, Oda H, et al: Importance of geranylgeranyl pyrophosphate for mesangial cell DNA synthesis. Kidney Int Suppl 1999;71:S80-S83.

43 Terada Y, Inoshita S, Nakashima O, et al: Lovastatin inhibits mesangial cell proliferation via p27Kip1. J Am Soc Nephrol 1998;9:22352243.

44 Vrtovsnik F, Couette S, Prie D, et al: Lovastatin-induced inhibition of renal epithelial tubular cell proliferation involves a p21ras-activated, AP-1-dependent pathway. Kidney Int 1997;52:1016-1027.

-45 Grandaliano G, Biswas P, Choudhury GG, et al: Simvastatin inhibits PDGF-induced DNA synthesis in human glomerular mesangial cells. Kidney Int 1993;44:503-508.
46 Ishikawa S, Kawasumi M, Saito T: Simvastatin inhibits the cellular signaling and proliferative action of arginine vasopressin in cultured rat glomerular mesangial cells. Endocrinology 1995;136:1954-1961.

47 Yoshimura A, Nemoto T, Sugenoya Y, et al: Effect of simvastatin on proliferative nephritis and cell-cycle protein expression. Kidney Int Suppl 1999;71:S84-S87.

48 Tao Y, Kim J, Schrier RW, et al: Rapamycin markedly slows disease progression in a rat model of polycystic kidney disease. J Am Soc Nephrol 2005;16:46-51.

49 Pallet N, Thervet E, Corre DL, et al: Rapamycin inhibits human renal epithelium cell proliferation: effect on cyclin D3 mRNA expression and stability. Kidney Int 2005;67: 2422-2433.

50 Lieberthal W, Fuhro R, Andry CC, et al: Rapamycin impairs recovery from acute renal failure: role of cell-cycle arrest and apoptosis of tubular cells. Am J Physiol Renal Physiol 2001; 281:F693-F706

-51 Asano T, Wakisaka M, Yoshinari M, et al: Peroxisome proliferator-activated receptor gamma1 (PPARgamma1) expresses in rat mesangial cells and PPARgamma agonists modulate its differentiation. Biochim Biophys Acta 2000;1497:148-154.

52 Ghosh SS, Gehr TW, Ghosh S, et al: PPARgamma ligand attenuates PDGF-induced mesangial cell proliferation: role of MAP kinase. Kidney Int 2003;64:52-62.

53 Haraguchi K, Shimura H, Onaya T: Suppression of experimental crescentic glomerulonephritis by peroxisome proliferator-activated receptor (PPAR)gamma activators. Clin Exp Nephrol 2003;7:27-32.

54 Zafiriou S, Stanners RS, Saad S, et al: Pioglitazone inhibits cell growth and reduces matrix production in human kidney fibroblasts. J Am Soc Nephrol 2005;16:638-645.

55 Tsuboi Y, Shankland SJ, Grande JP, et al: Suppression of mesangial proliferative glomerulonephritis development in rats by inhibitors of cAMP phosphodiesterase isozymes types III and IV. J Clin Invest 1996;98:262-270.

56 Matousovic K, Tsuboi Y, Walker H, et al: Inhibitors of cyclic nucleotide phosphodiesterase isozymes block renal tubular cell proliferation induced by folic acid. J Lab Clin Med 1997; 130:487-495.

-57 Lin SL, Chen RH, Chen YM, et al: Pentoxifylline inhibits platelet-derived growth factorstimulated cyclin D1 expression in mesangial cells by blocking Akt membrane translocation. Mol Pharmacol 2003;64:811-822.

58 Strutz F, Heeg M, Kochsiek T, et al: Effects of pentoxifylline, pentifylline and gamma-interferon on proliferation, differentiation, and matrix synthesis of human renal fibroblasts. Nephrol Dial Transplant 2000;15:15351546.

59 Chen YM, Chien CT, Hu-Tsai MI, et al: Pentoxifylline attenuates experimental mesangial proliferative glomerulonephritis. Kidney Int 1999;56:932-943.
60 Futamura A, Izumino K, Nakagawa Y, et al: Effect of the platelet-derived growth factor antagonist trapidil on mesangial cell proliferation in rats. Nephron 1999;81:428-433.

-61 Gesualdo L, Di Paolo S, Ranieri E, et al: Trapidil inhibits human mesangial cell proliferation: effect on PDGF beta-receptor binding and expression. Kidney Int 1994;46:1002-1009.

-62 Gilbert RE, Kelly DJ, McKay T, et al: PDGF signal transduction inhibition ameliorates experimental mesangial proliferative glomerulonephritis. Kidney Int 2001;59:1324-1332.

63 Yagi M, Kato S, Kobayashi Y, et al: Selective inhibition of platelet-derived growth factor (PDGF) receptor autophosphorylation and PDGF-mediated cellular events by a quinoline derivative. Exp Cell Res 1997;234:285-292.

-64 Utsunomiya Y, Ogura M, Kawamura T, et al: Attenuation of immune complex nephritis in NZB/WF1 mice by a prostacyclin analogue. Clin Exp Immunol 1995;99:454-460.

65 Makita Y, Sekizuka K, Wang LN, et al: Effect of beraprost sodium, a $\mathrm{PGI}_{2}$ analogue, on proliferation of cultured rat glomerular mesangial cells. Nephron 1996;74:228.

66 Togawa M, Haneda M, Araki S, et al: Beraprost sodium, an analogue of prostacyclin, induces the expression of mitogen-activated protein kinase phosphatase and inhibits the proliferation of cultured mesangial cells. Eur J Pharmacol 1997;336:291-294.

67 Kushiro M, Shikata K, Sugimoto H, et al: Therapeutic effects of prostacyclin analog on crescentic glomerulonephritis of rat. Kidney Int 1998;53:1314-1320.

68 Yamada M, Sasaki R, Sato N, et al: Amelioration by beraprost sodium, a prostacyclin analogue, of established renal dysfunction in rat glomerulonephritis model. Eur J Pharmacol 2002;449:167-176.

-69 Clarke HC, Kocher HM, Khwaja A, et al: Ras antagonist farnesylthiosalicylic acid (FTS) reduces glomerular cellular proliferation and macrophage number in rat thy- 1 nephritis. $\mathrm{J}$ Am Soc Nephrol 2003;14:848-854.

70 Wagner J, Dechow C, Morath C, et al: Retinoic acid reduces glomerular injury in a rat model of glomerular damage. J Am Soc Nephrol 2000;11:1479-1487.

71 Simonson MS: Anti-AP-1 activity of all-trans retinoic acid in glomerular mesangial cells. Am J Physiol 1994;267:F805-F815.

72 Dechow C, Morath C, Peters J, et al: Effects of all-trans retinoic acid on renin-angiotensin system in rats with experimental nephritis. Am J Physiol Renal Physiol 2001;281:F909-F919.

73 Altieri P, Caridi G, Chiesa V, et al: N-(4-hydroxyphenyl) retinamide inhibits cystogenesis by polycystic epithelial cell lines in vitro. Life Sci 1999;64:PL259-PL265.

74 Lehrke I, Schaier M, Schade K, et al: Retinoid receptor-specific agonists alleviate experimental glomerulonephritis. Am J Physiol Renal Physiol 2002;282:F741-F751. 
75 Schaier M, Liebler S, Schade K, et al: Retinoic acid receptor alpha and retinoid $\mathrm{X}$ receptor specific agonists reduce renal injury in established chronic glomerulonephritis of the rat. $\mathrm{J}$ Mol Med 2004;82:116-125.

-76 Vaughan MR, Pippin JW, Griffin SV, et al: ATRA induces podocyte differentiation and alters nephrin and podocin expression in vitro and in vivo. Kidney Int 2005;68:133-144.

77 Belibi FA, Reif G, Wallace DP, et al: Cyclic AMP promotes growth and secretion in human polycystic kidney epithelial cells. Kidney Int 2004;66:964-973.
78 Yamaguchi T, Nagao S, Wallace DP, et al: Cyclic AMP activates B-Raf and ERK in cyst epithelial cells from autosomal-dominant polycystic kidneys. Kidney Int 2003;63:19831994.

79 Torres VE, Wang X, Qian Q, et al: Effective treatment of an orthologous model of autosomal dominant polycystic kidney disease. Nat Med 2004;10:363-364.

80 Gattone VH 2nd, Wang X, Harris PC, et al: Inhibition of renal cystic disease development and progression by a vasopressin $\mathrm{V}_{2}$ receptor antagonist. Nat Med 2003;9:1323-1326.
81 Gattone VH 2nd, Maser RL, Tian C, et al: Developmental expression of urine concentration-associated genes and their altered expression in murine infantile-type polycystic kidney disease. Dev Genet 1999;24:309-318.

82 Wang X, Gattone VH, Harris PC, et al: Effectiveness of vasopressin $\mathrm{V}_{2}$ receptor antagonists OPC-31260 and OPC-41061 on polycystic kidney disease development in the PCK rat. J Am Soc Nephrol 2005; 16:846-851.

83 Milovanceva-Popovska M, Kunter U, Ostendorf T, et al: R-roscovitine (CYC202) alleviates renal cell proliferation in nephritis without aggravating podocyte injury. Kidney Int 2005; 67:1362-1370. 